\title{
Monitoring of Chemical Changes in Explosively Puffed Ginseng and the Optimization of Puffing Conditions
}

\author{
Sung-Ran Yoon ${ }^{1}$, Gee-Dong Lee ${ }^{2}$, Hyun-Ku Kim ${ }^{3}$ and Joong-Ho Kwon ${ }^{1 *}$ \\ ${ }^{1}$ Department of Food Science and Technology / Food \& Bio-Industry Research Institute, \\ Kyungpook National University, Daegu 702-701, Korea \\ ${ }^{2}$ Daegu Technopark Bio Industry Center, Daegu 704-230, Korea \\ ${ }^{3}$ Korea Food Research Institute, Gyeonggi 463-746, Korea \\ (Received January 15, 2009; Revised February 1, 2009; Accepted February 4, 2009)
}

\begin{abstract}
Response surface methodology was used to predict the optimum conditions of explosive puffing process for ginseng. A central composite design was used to monitor the effect of moisture content and puffing pressure on dependent variables such as functional compounds (extract yield, crude saponin, acidic polysaccharide, and total phenolic content) and sensory properties. Correlation coefficients $\left(\mathrm{R}^{2}\right)$ of models for crude saponin, acidic polysaccharide, and total phenolic content were $0.9176(p<0.05), 0.9494(p<0.05)$, and 0.9878 ( $p<0.001)$, respectively. Functional compounds increased with decreasing moisture content and increasing puffing pressure. Overall palatability was high at $15-20 \%$ moisture content and 98-294 $\mathrm{kPa}$ of puffing pressure. On the basis of superimposed contour maps for functional compounds and overall palatability of puffed ginseng, the optimum ranges of puffing conditions were 10-17\% moisture content and 294-392 $\mathrm{kPa}$ puffing pressure.
\end{abstract}

Key words : ginseng, puffing, functional compounds, sensory property, response surface methodology

\section{INTRODUCTION}

Ginseng (Panax ginseng) has long been used as a traditional drug in oriental medicine. Functional ingredients in ginseng include saponins, phenolic compounds, polyacetylenes, alkaloids, and polysaccharides [1]. Raw ginseng is processed into white and red ginseng, to improve its shelflife and efficacy [2]. White ginseng is usually airdried raw ginseng, while red ginseng is usually made by first steaming raw ginseng and then air-drying it [3]. Red ginseng is known to be more pharmaceutically active than white ginseng because the steaming process produces different vital compounds that are not present in white ginseng, thereby enhancing the biological activity of the ginseng.

Puffing is one of food processing method that weakens the binding forces in plant tissues by heating treatment, and therefore facilitates the solubilization of functional components. Furthermore, the original structure can be broken down during the puffing process due to an increase in specific volume of moisture or gas in samples [4-6]. Among food processing methods, high-temperature

* Corresponding author. E-mail: jhkwon@knu.ac.kr Phone: +82-53-950-5775, Fax: +82-53-950-6772 and short-time puffing processes cause various changes in foods and herbal medicines such as starch gelatinization, denaturation and texturization of proteins, enzyme inactivation, destruction of harmful substances, changes in ingredients, and deodorization [7-9]. Puffing is usually used for cereals and beans where key points in the degree of volume expansion are the momentary changes in temperature and pressure [10]. During extrusion process, a variety of steps, including mixing, cutting, heating, forming, and drying, occur within a short time [11], where high temperature, pressure, and shear rate can facilitate the increase in soluble components [12].

In the case of ginseng, formation of the unique red ginseng components, such as $\mathrm{Rh}_{2}, \mathrm{Rg}_{3}, \mathrm{Rh}_{1}$, and $\mathrm{Rh}_{4}$, were reported after extrusion [13]. Puffing process changes the physicochemical properties of the components, such as starch gelatinization and tissue expansion. Therefore it is being applied for producing a variety of food product to improve taste and texture. Although ginseng shows various physiological activities even without appropriate processing, the bioavailability tends to be very low as the structure of the cell walls is tough and rigid. Generally, steaming or roasting methods are inefficient for changing 
the microstructure of ginseng. Different studies revealed quality properties and moisture absorption of puffed red ginseng $[9,14]$. However, no study on puffing raw ginseng has been reported yet.

Moisture, the driving force in forming air holes during the puffing process, and puffing pressure should be carefully considered in the process. Thus, the present study was performed to monitor the effects of moisture content and puffing pressure on extract yield, crude saponin, acidic polysaccharide, total phenolic content, and sensory properties by using response surface methodology (RSM) to establish optimal puffing conditions.

\section{MATERIALS AND METHODS}

\section{Materials}

Four year old ginseng roots were purchased from the Punggi wholesale market in Korea. The ginseng roots were washed and cut into $2 \mathrm{~mm}$ slices.

\section{Puffing procedure}

The sliced ginseng was dried at $60^{\circ} \mathrm{C}$ for $24 \mathrm{~h}$. To get desired moisture content $(5,10,15,20,25 \%)$, the dried ginseng samples were sprayed with appropriate amount of moisture and were placed in airtight containers for $24 \mathrm{~h}$. A rotary puffing machine (capacity: $5 \mathrm{~L}$, maximum pressure: $1470 \mathrm{kPa}$; Jeil Machine Co., Daegu, Korea) was used. The screw speed and puffing time were $50 \mathrm{rpm}$ and $10 \mathrm{~min}$, respectively. After adding samples (500 g), explosive puffing was carried out on desired pressure $(98,196$,
294, 392, or $490 \mathrm{kPa}$ ). After puffing, the product samples were cooled to room temperature, ground with 80 mesh, sealed, and stored.

\section{Response surface methodology}

RSM was used to investigate changes in ginseng components after puffing raw ginseng. RSM enabled the evaluation of the effects of many factors and their interactions on response variables. Thus, RSM is a collection of statistical and mathematical techniques that have been successfully used for developing, improving and optimizing processes [15]. Based on a central composite design [16], 10 experimental settings were obtained by independent variables, such as moisture content $\left(\mathrm{X}_{1}: 5,10,15,20,25 \%\right)$ and puffing pressure $\left(\mathrm{X}_{2}: 98,196,294,392,490 \mathrm{kPa}\right)$. The actual variable (5 experimental levels, -2, -1, 0, 1, 2) was coded to facilitate multiple regression analysis (Table 1). All statistical analyses were performed using SAS software (ver. 8.0; SAS Institute Inc., Cary, NC, USA). The dependent variables $(\mathrm{Y})$ were extract yield, crude saponin, acidic polysaccharide, total phenolic, and sensory evaluation. The quadratic regression model equation for the dependent and independent variables could be predicted as follows: $Y=\beta_{0}+\beta_{1} X_{1}+\beta_{2} X_{2}+\beta_{11} X_{1}^{2}+\beta_{22} X_{2}^{2}+\beta_{12} X_{1} X_{2}$ where $Y$ represents the dependent variables, $X_{1}$ and $X_{2}$ are independent variables, $\beta_{0}$ is the intercept, and $\beta_{\mathrm{n}}$ is the coefficient.

\section{Extract yield}

Distilled water $(100 \mathrm{~mL})$ was added to a puffed ginseng

Table 1. Experimental data ${ }^{1)}$ on extract yield, crude saponin, acidic polysaccharide, and total phenolic content of explosively puffed ginseng under different conditions based on central composite design for response surface analysis

\begin{tabular}{|c|c|c|c|c|c|c|}
\hline \multirow[b]{2}{*}{ Exp. No. ${ }^{2)}$} & \multicolumn{2}{|c|}{ Puffing condition } & \multirow[b]{2}{*}{$\begin{array}{l}\text { Extract yield } \\
(\%)\end{array}$} & \multirow[b]{2}{*}{$\begin{array}{l}\text { Crude saponin } \\
\text { content }(\mathrm{mg} / \mathrm{g})\end{array}$} & \multirow{2}{*}{$\begin{array}{c}\text { Acidic } \\
\text { polysaccharide } \\
\text { content }(\mathrm{mg} / \mathrm{g})\end{array}$} & \multirow[b]{2}{*}{$\begin{array}{l}\text { Total phenolic } \\
\text { content }(\mathrm{mg} / \mathrm{g})\end{array}$} \\
\hline & $\begin{array}{c}\text { Moisture content } \\
(\%)\end{array}$ & $\begin{array}{l}\text { Puffing pressure } \\
(\mathrm{kPa})\end{array}$ & & & & \\
\hline & Control $^{3)}$ & & 51.99 & 51.69 & 30.17 & 6.15 \\
\hline 1 & $20(1)$ & $392(1)$ & 54.52 & 68.44 & 36.71 & 14.64 \\
\hline 2 & $20(1)$ & $196(-1)$ & 53.86 & 62.30 & 32.04 & 7.37 \\
\hline 3 & $10(-1)$ & $392(1)$ & 55.72 & 75.67 & 44.48 & 28.92 \\
\hline 4 & $10(-1)$ & $196(-1)$ & 53.11 & 58.04 & 34.26 & 18.54 \\
\hline 5 & $15(0)$ & $294(0)$ & 55.87 & 73.98 & 38.00 & 11.76 \\
\hline 6 & $15(0)$ & $294(0)$ & 55.74 & 72.46 & 37.59 & 13.80 \\
\hline 7 & $25(2)$ & $294(0)$ & 53.89 & 63.73 & 30.72 & 7.52 \\
\hline 8 & $15(0)$ & $490(2)$ & 56.33 & 74.68 & 42.73 & 25.22 \\
\hline 9 & $5(-2)$ & $294(0)$ & 53.35 & 75.57 & 39.23 & 32.44 \\
\hline 10 & $15(0)$ & $98(-2)$ & 53.60 & 52.90 & 34.98 & 9.44 \\
\hline
\end{tabular}

\footnotetext{
1) Means $(\mathrm{n}=3)$.

2) Number of experimental conditions by central composite design.

3) Ginseng dried at $60^{\circ} \mathrm{C}$ for $24 \mathrm{~h}$.
} 
sample $(1 \mathrm{~g})$, and then the mixture was extracted at $95^{\circ} \mathrm{C}$ for $2 \mathrm{~h}$. After the extract was filtered (Whatman No. 41), it was adjusted to $100 \mathrm{~mL}$. To measure extract yield, the filtered extract $(20 \mathrm{~mL})$ was placed in a container and dried at $105^{\circ} \mathrm{C}$. After drying, the weight was measured. The extract yield was calculated as follows:

Extract yield $(\%)=$ [weight of sample after drying/sample weight (dry basis)] $\times 100$.

All treatments were carried out in triplicate.

\section{Crude saponin content}

The crude saponin content was investigated according to the methods described by Namba [17] and Ando [18]. $5 \mathrm{~g}$ of ginseng powder and $100 \mathrm{~mL}$ of $80 \%$ methanol were placed in a round flask and extracted in a water bath at $80^{\circ} \mathrm{C}$ for $2 \mathrm{~h}$. The extraction was repeated four times. The extracted samples were filtered (Whatman No. 41), centrifuged (8,000 rpm, $20 \mathrm{~min})$, and evaporated. The evaporated residue was dissolved in $50 \mathrm{~mL}$ distilled water and washed 2 times with $50 \mathrm{~mL}$ diethyl ether to remove the lipids using a separatory funnel. The aqueous layer was extracted 4 times with $50 \mathrm{~mL}$ of water-saturated nbutanol. The butanol solution was washed twice with 30 $\mathrm{mL}$ distilled water to remove impurities. The remaining butanolic solution was transferred to a round-bottom flask. The solvent was removed using a rotary evaporator at $55^{\circ} \mathrm{C}$. After evaporation, the flask was dried at $105^{\circ} \mathrm{C}$, cooled in a desiccator, and monitored until constant weight. This weight was then compared to the original weight of the empty flask. The weight difference corresponded to the amount of the soluble solids (crude saponin) of the sample.

\section{Acidic polysaccharide content}

The acidic polysaccharide content of the ginseng was analyzed by the carbazole-sulfuric acid method [19]. In $0.5 \mathrm{~mL}$ of ginseng extract, $0.25 \mathrm{~mL}$ of carbazole and 3
$\mathrm{mL}$ of conc. $\mathrm{H}_{2} \mathrm{SO}_{4}$ were added and mixed at $80^{\circ} \mathrm{C}$ for 5 $\min$. The mixture was cooled to room temperature and the absorbance was measured (UVmini-1240; Shimadzu, Tokyo, Japan). $\beta$-D-Galacturonic acid (Sigma-Aldrich, St. Louis, MO, USA) was used as a standard.

\section{Total phenolic content}

The total phenolic content of ginseng extract was colorimetrically measured using the Folin-Denis method [20]. Ginseng extract $(2 \mathrm{~mL})$ was mixed with $2 \mathrm{~mL}$ of FolinCiocalteu reagent for $3 \mathrm{~min}$. The mixture was combined with $2 \mathrm{~mL}$ of $10 \% \mathrm{Na}_{2} \mathrm{CO}_{3}$, heated for $1 \mathrm{~h}$, and cooled. The absorbance was measured at $700 \mathrm{~nm}$ using a spectrophotometer (UVmini-1240; Shimadzu). The total phenolic content was calculated on a basis of a standard curve, which was obtained using various concentrations (5-50 $\mu \mathrm{g} / \mathrm{mL})$ of gallic acid (Sigma-Aldrich).

\section{Sensory analysis}

Fifteen trained sensory panelists evaluated the randomly coded samples. Color, savory smell, savory taste, and overall palatability were investigated on a 9-point scale (1 $=$ very poor, $3=$ poor, $5=$ fair, $7=$ good, and $9=$ very good) [21].

\section{RESULTS AND DISCUSSION}

\section{Change in extract yield}

Experimental data on extract yield of explosively puffed ginseng under different conditions, designed on the basis of a central composite design, are shown in Table 1 . The extract yield of the non-puffed ginseng was $51.99 \%$, while extract yields increased slightly (53.11-56.33\%) after the puffing process. The polynomial equation calculated by the RSM program on extract yield for explosively puffed ginseng is presented in Table 2 . The value of the correlation coefficient $\left(\mathrm{R}^{2}\right)$ was 0.8851 , indicating sig-

Table 2. Polynomial equations calculated by the RSM program for extract yield, crude saponin, acidic polysaccharide, and total phenolic content for explosively puffed ginseng

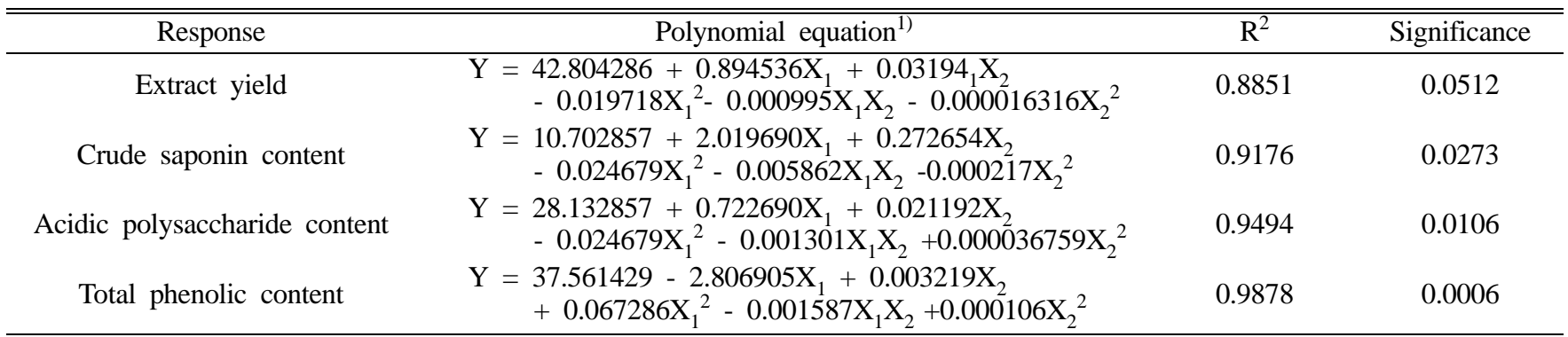

1) $\mathrm{X}_{1}$ : moisture content $(\%), \mathrm{X}_{2}:$ puffing pressure $(\mathrm{kPa})$. 

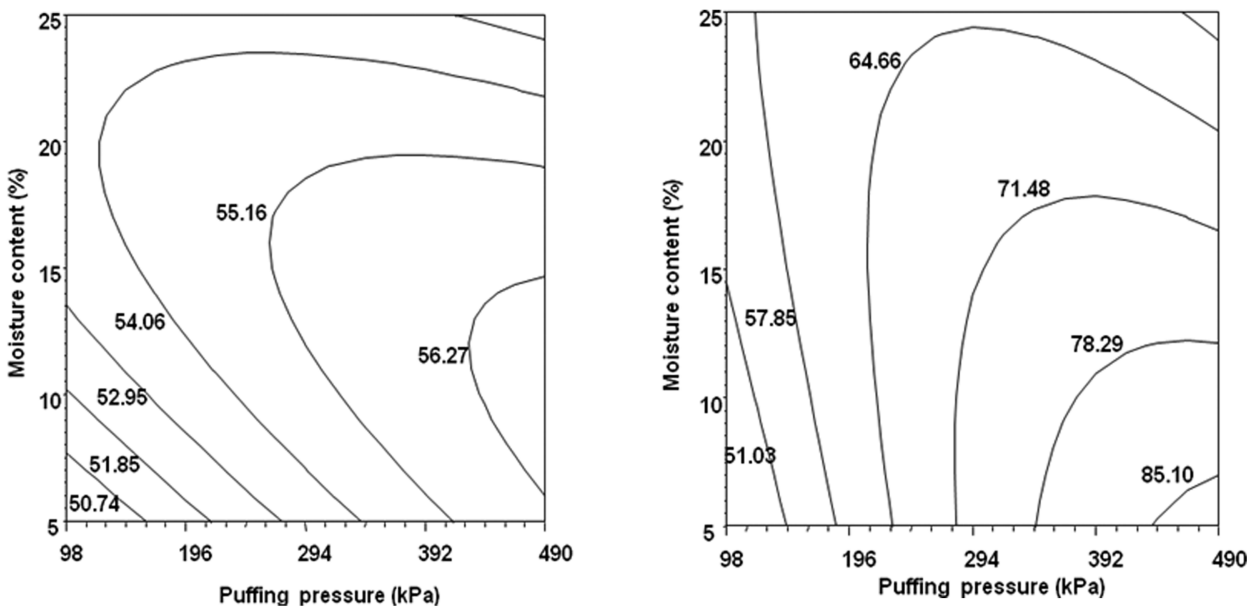

(A)

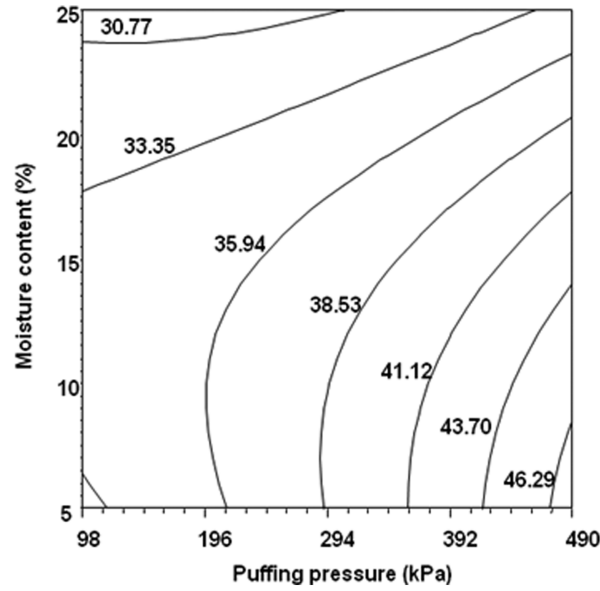

(B)

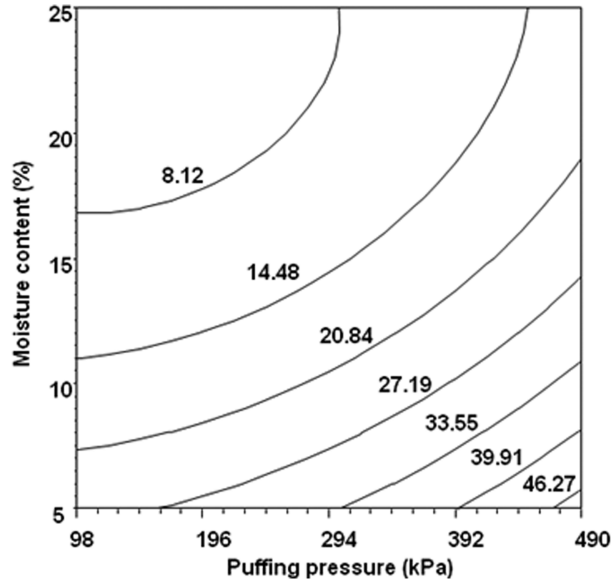

(D)

Fig. 1. Contour map for extract yield (A), crude saponin (B), acidic polysaccharide (C), and total phenolic content (D) of explosively puffed ginseng as a function of moisture content and puffing pressure.

Table 3. Predicted levels of optimum puffing conditions for extract yield, crude saponin, acidic polysaccharide, and total phenolic content of explosively puffed ginseng by ridge analysis

\begin{tabular}{ccccc}
\hline \hline \multirow{2}{*}{ Responses } & \multicolumn{2}{c}{ Puffing condition } & \multirow{2}{*}{ Maximum } & \multirow{2}{*}{ Morphology } \\
\cline { 2 - 3 } & Moisture content $(\%)$ & Puffing pressure $(\mathrm{kPa})$ & & \\
\hline Extract yield $(\%)$ & 11.53 & 477.80 & 56.55 & Maximum \\
Crude saponin content $(\mathrm{mg} / \mathrm{g})$ & 7.71 & 428.22 & 82.46 & Saddle point \\
Acidic polysaccharide content $(\mathrm{mg} / \mathrm{g})$ & 10.55 & 469.53 & 44.62 & Saddle point \\
Total phenolic content $(\mathrm{mg} / \mathrm{g})$ & 6.36 & 392.65 & 36.10 & Minimum \\
\hline
\end{tabular}

nificance at a $10 \%$ level (Table 2). The contour map of the extract yield suggested that the extract yield increased with decreasing moisture content and increasing puffing pressure (Fig. 1A). The predicted levels of optimum puffing conditions on the maximum extract yield $(56.55 \%)$ were $11.53 \%$ moisture content and $477.80 \mathrm{kPa}$ puffing pressure (Table 3). Ryu and Remon [12] also reported that the extract yield for extruded raw ginseng increased with a decrease in moisture content and an increase in screw speed.

\section{Change in crude saponin content}

The amount and composition of ginseng saponin is well-known to change considerably during the steaming process $[22,23]$. The crude saponin content of explosively puffed ginseng samples are presented in Table 1 . The crude saponin content of non-puffed ginseng was $51.69 \mathrm{mg} / \mathrm{g}$, 
while the crude saponin content of explosively puffed ginseng samples produced at $15 \%$ moisture content and 98 $\mathrm{kPa}$ puffing pressure was $52.90 \mathrm{mg} / \mathrm{g}$ and that of at $10 \%$ moisture content and $392 \mathrm{kPa}$ puffing pressure was 75.67 $\mathrm{mg} / \mathrm{g}$. Based on the crude saponin content of explosively puffed ginseng samples produced under different puffing conditions, a quadratic equation was obtained and the value of $\mathrm{R}^{2}$ was 0.9176 , indicating significance at the $5 \%$ level (Table 2). Fig. 2B shows the contour map obtained from the equation. The crude saponin content of explosively puffed ginseng increased with reduced moisture content and increased puffing pressure. Generally, crude saponin content was more affected by puffing pressure than by moisture content. The maximum value $(82.46 \mathrm{mg} / \mathrm{g})$ of the crude saponin content predicted by RSM was obtained at $7.71 \%$ moisture content and $428.22 \mathrm{kPa}$

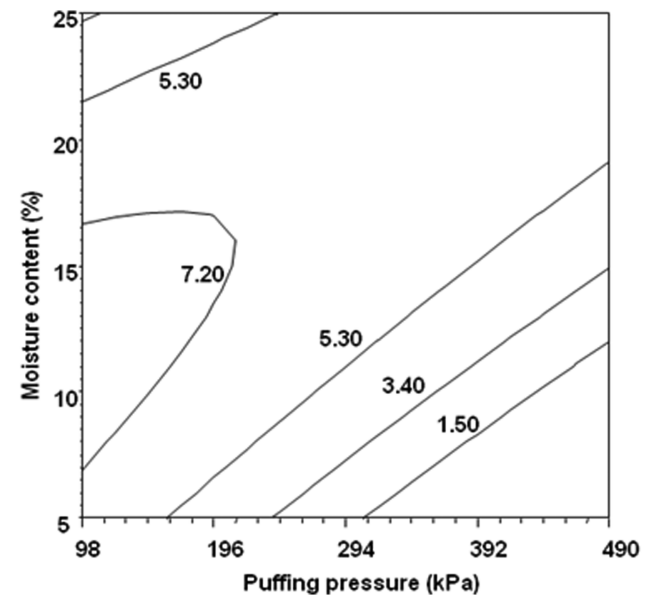

(A)

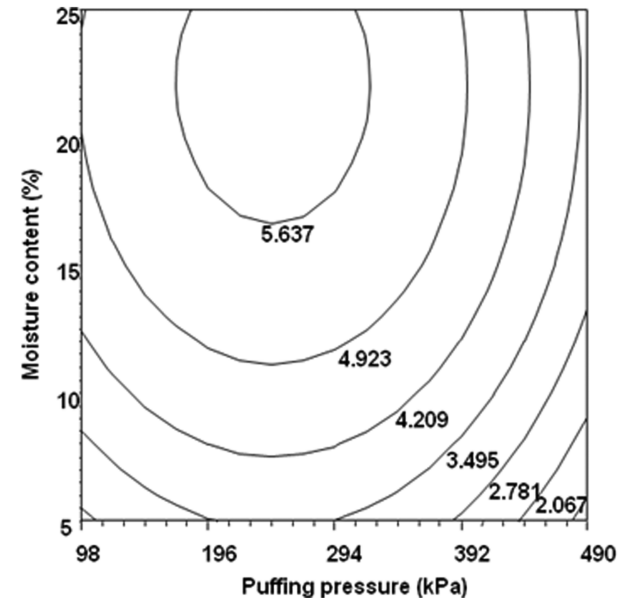

(C) puffing pressure (Table 3). An increase in the crude saponin content after puffing was also found in the study by Han et al. [9], who reported that crude saponin content increased from $7.86 \%$ to $9.94 \%$ after puffing red ginseng tail root. Ha and Ryu [24] studied the effect of extrusion processing on crude saponin content and noted that crude saponin content of red ginseng, white ginseng with skin, and white ginseng were $4.02 \%, 3.56 \%$, and $3.25 \%$, respectively, while the crude saponin content of the ginseng samples extruded at 25\% and 35\% moisture content were $4.77 \%$ and $4.12 \%$, respectively. According to their report [24], the higher content of crude saponin could be explained by the fact that shear force occurred during the extrusion process, destroying the cell wall structure of ginseng, thereby allowing easier extraction of these components. They also reported that extrusion process with

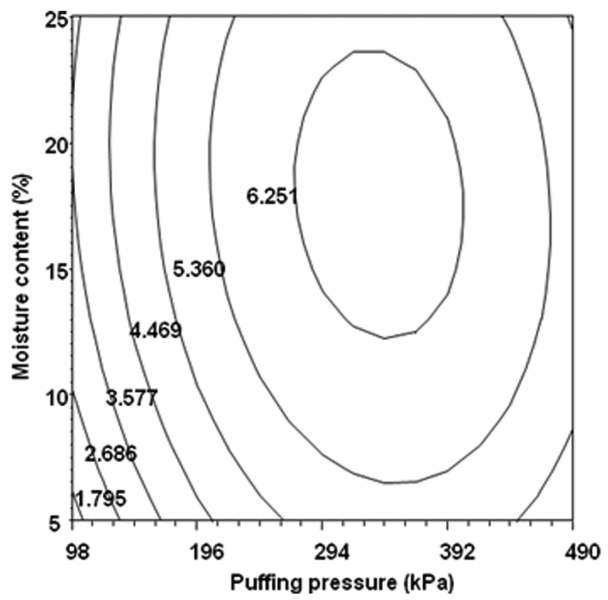

(B)

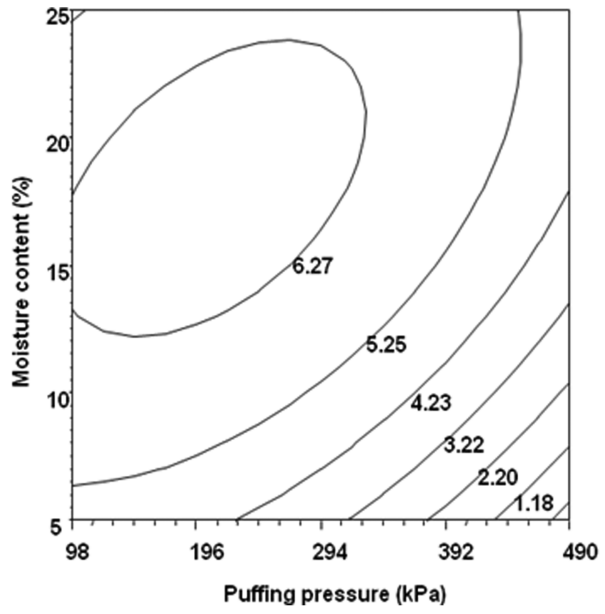

(D)

Fig. 2. Contour map for sensory properties (A, color; B, savory smell; C, savory taste; D, overall palatability) of explosively puffed ginseng as a function of moisture content and puffing pressure. 
lower moisture content could increase the transformation of the cell wall structures. Additionally, Park et al. [25] reported that some polar ginseng saponins changed into nonpolar saponins, which had lower molecular weights during the roasting of ginseng. In the present study, an increase in crude saponin content during the puffing process could be associated with the facilitation of crude saponin solubilization caused by the destruction of cell walls, as well as with a reduction in saponin molecular weight by heat treatment.

\section{Change in acidic polysaccharide content}

Ginseng polysaccharides have been reported to antagonize toxohormone-L, causing reductions in body fat, loss of appetite in patients with cancer, and reductions in body weight $[26,27]$. The acidic polysaccharide content of nonpuffed ginseng was $30.17 \mathrm{mg} / \mathrm{g}$, while the acidic polysaccharide content of explosively puffed ginseng samples ranged from 30.72 to $44.48 \mathrm{mg} / \mathrm{g}$, depending on puffing conditions. Based on these results, a quadratic equation was obtained, and the $\mathrm{R}^{2}$ value was 0.9494 , indicating significance at the $5 \%$ level (Table 2). The contour map obtained from the equation is illustrated in Fig. 1C. The acidic polysaccharide content increased with decreasing moisture content and with increasing puffing pressure. The maximum value $(44.62 \mathrm{mg} / \mathrm{g})$ of acidic polysaccharide content was obtained at $10.55 \%$ moisture content and $469.53 \mathrm{kPa}$ puffing pressure (Table 3). Ha and Ryu [24] reported that the higher acidic polysaccharide content in extruded ginseng could be related to the increased extraction rate of starch and carbohydrate from extruded ginseng, which experienced shear force and pressure as a result of thermal and mechanical energy during the extrusion process. Moreover, the acidic polysaccharide content $(6.2-8.3 \%)$ of red ginseng was reported to be higher than that $(4.9 \%)$ of white ginseng [28]. The higher polysaccharide content in red ginseng could be due to the hydrolysis of sugars through heat treatment and repeated dehydration in producing red ginseng, although the mechanism is still unclear. The findings suggest that the increase in the acidic polysaccharide content in the present study could be related to high shear force, pressure, and temperature occurring in the puffing process.

\section{Change in total phenolic content}

Table 1 shows the total phenolic content of explosively puffed ginseng produced under different moisture content and puffing pressure conditions. The total phenolic content of non-puffed ginseng was $6.15 \mathrm{mg} / \mathrm{g}$, whereas the total phenolic content of explosively puffed ginseng ranged from 7.37 to $32.44 \mathrm{mg} / \mathrm{g}$, depending on puffing conditions. Based on these results, a quadratic equation was obtained and the $\mathrm{R}^{2}$ value was 0.9878 , indicating significance at a $5 \%$ level (Table 2). Fig. 1D shows the contour map obtained from the equation. The total phenolic content increased with the decreasing moisture content and increasing puffing pressure. The maximum value $(36.10 \mathrm{mg} / \mathrm{g})$ of total phenolic content was obtained at $6.36 \%$ moisture content and $392.65 \mathrm{kPa}$ puffing pressure (Table 3). The phenolic acid components of ginseng include salicylic acid, p-hydroxybenzoic acid, gentisic acid, protocatechuic acid, vanillin acid, syringic acid, cinnamic acid, $m$-coumaric acid, $p$-coumaric acid, caffeic acid, ferulic acid, and maltol [3]. Han et al. [9] reported that the amounts of gallic acid, $p$-coumaric acid, caffeic acid, and ferulic acid decreased and the amount of syringic acid increased sixfold after puffing red ginseng tail. In the study conducted by Kim et al. [29], total phenolic content of raw ginseng increased from $0.53 \%$ to $2.89 \%$, depending on the frequency of steaming. Furthermore, Yang et al. [30] reported that total phenolic content in raw ginseng treated by high temperature and pressure increased with increasing temperature and time. In the present study, the total phenolic content could be increased by heat treatment during the puffing process, indicating that the bound phenolic components became free phenolic components as a result of heat treatment, thereby facilitating the extraction of phenolic components. The increased total phenolic content could be also related to the conversion of higher molecular weight phenolic compounds into lower molecular weight phenolic compounds [31-34]. However, more research on this issue is needed.

\section{Change in sensory properties}

Puffing, which uses high temperature for a short time, accelerates the browning reaction and improves palatability, with the production of volatile flavor components [79]. Experimental data on sensory properties (color, savory smell, savory taste, and overall palatability) of explosively puffed ginseng under different conditions are presented in Table 4. Color, savory smell, savory taste, and overall palatability scores ranged from 1.67 to $8.33,2.33$ to 7.00 , 3.00 to 6.67 , and 3.00 to 7.33 , respectively. Based on the results in Table 4, quadratic equations were obtained (Table 5). The $\mathrm{R}^{2}$ value for color was 0.8976 , indicating significance at the $5 \%$ level. The $\mathrm{R}^{2}$ values for savory smell, savory taste, and overall palatability were less than 0.8 , suggesting that the relationships were not significant. 
Table 4. Experimental data on sensory properties of explosively puffed ginseng under different conditions, based on central composite design for response surface analysis

\begin{tabular}{ccccccc}
\hline \hline \multirow{2}{*}{ Exp. No. ${ }^{1)}$} & \multicolumn{2}{c}{ Puffing condition } & \multicolumn{3}{c}{ Sensory property ${ }^{2}$} \\
\cline { 2 - 7 } & $\begin{array}{c}\text { Moisture content } \\
(\%)\end{array}$ & $\begin{array}{c}\text { Puffing pressure } \\
(\mathrm{kPa})\end{array}$ & Color & $\begin{array}{c}\text { Savory } \\
\text { smell }\end{array}$ & $\begin{array}{c}\text { Savory } \\
\text { taste }\end{array}$ & $\begin{array}{c}\text { Overall } \\
\text { palatability }\end{array}$ \\
\hline 1 & $20(1)$ & $392(1)$ & 7.00 & 5.67 & 4.33 & 6.17 \\
2 & $20(1)$ & $196(-1)$ & 5.67 & 5.33 & 4.67 & 5.33 \\
3 & $10(-1)$ & $392(1)$ & 3.67 & 4.67 & 4.00 & 4.33 \\
4 & $10(-1)$ & $196(-1)$ & 6.00 & 4.00 & 4.33 & 4.67 \\
5 & $15(0)$ & $294(0)$ & 6.67 & 7.00 & 6.67 & 7.00 \\
6 & $15(0)$ & $294(0)$ & 6.33 & 6.67 & 5.00 & 6.00 \\
7 & $25(2)$ & $294(0)$ & 6.00 & 6.00 & 6.33 & 6.33 \\
8 & $15(0)$ & $490(2)$ & 2.67 & 5.67 & 3.00 & 3.00 \\
9 & $5(-2)$ & $294(0)$ & 1.67 & 5.33 & 3.33 & 3.67 \\
10 & $15(0)$ & $98(-2)$ & 8.33 & 2.33 & 5.00 & 7.33 \\
\hline
\end{tabular}

1) Number of experimental conditions by central composite design.

2) Means $(n=15)$ and sensory score (1: very poor, 9: very good).

Table 5. Polynomial equations calculated by the RSM program for sensory properties for explosively puffed ginseng

\begin{tabular}{|c|c|c|c|}
\hline Response & Polynomial equation $^{1)}$ & $\overline{\mathrm{R}^{2}}$ & Significance \\
\hline Color & $\begin{aligned} \mathrm{Y}= & 6.652857+0.444940 \mathrm{X}_{1}-0.023175 \mathrm{X}_{2} \\
& -0.026654 \mathrm{X}_{1}^{2}+0.001867 \mathrm{X}_{1} \mathrm{X}_{2}-0.000026040 \mathrm{X}_{2}^{2}\end{aligned}$ & 0.8976 & 0.0413 \\
\hline Savory smell & $\begin{aligned} \mathrm{Y}= & -5.104286+0.383131 \mathrm{X}_{1}+0.048451 \mathrm{X}_{2} \\
& -0.009082 \mathrm{X}_{1}^{2}-0.000168 \mathrm{X}_{1} \mathrm{X}_{2}-0.000066983 \mathrm{X}_{2}^{2}\end{aligned}$ & 0.7969 & 0.1453 \\
\hline Savory taste & $\begin{aligned} \mathrm{Y}= & -0.511429+0.346238 \mathrm{X}_{1}+0.020726 \mathrm{X}_{2} \\
& -0.007786 \mathrm{X}_{1}^{2}-0.000005102 \mathrm{X}_{1} \mathrm{X}_{2}-0.000041872 \mathrm{X}_{2}^{2}\end{aligned}$ & 0.6707 & 0.3283 \\
\hline Overall palatability & $\begin{aligned} \mathrm{Y}= & 3.337143+0.346226 \mathrm{X}_{1}+0.001551 \mathrm{X}_{2} \\
& -0.013096 \mathrm{X}_{1}^{2}+0.000602 \mathrm{X}_{1} \mathrm{X}_{2}-0.000029796 \mathrm{X}_{2}^{2}\end{aligned}$ & 0.7083 & 0.2699 \\
\hline
\end{tabular}

1) $\mathrm{X}_{1}$ : moisture content $(\%), \mathrm{X}_{2}$ : puffing pressure $(\mathrm{kPa})$.

Table 6. Predicted levels of optimum puffing conditions for sensory properties of explosively puffed ginseng by ridge analysis

\begin{tabular}{ccccc}
\hline \hline \multirow{2}{*}{ Response } & \multicolumn{2}{c}{ Puffing condition } & \multirow{2}{*}{ Maximum } & \multirow{2}{*}{ Morphology } \\
\cline { 2 - 3 } & Moisture content $(\%)$ & Puffing pressure $(\mathrm{kPa})$ & & Saddle point \\
Color & 14.50 & 104.23 & 6.78 & Maximum \\
Savory smell & 18.23 & 340.23 & 5.87 & Maximum \\
Savory taste & 22.59 & 244.74 & 6.61 & Maximum \\
Overall palatability & 17.91 & 214.30 & &
\end{tabular}

The contour maps of explosively puffed ginseng on sensory properties as a function of moisture content and puffing pressure are illustrated in Fig. 2. Higher scores of color, savory smell, savory taste, and overall palatability were obtained at $10-15 \%$ moisture content and $196 \mathrm{kPa}$ puffing pressure, 15-20\% moisture content, and 294-392 $\mathrm{kPa}$ puffing pressure, 20-25\% moisture content and 196-294 kPa puffing pressure, and 15-20\% moisture content and 98-294 kPa puffing pressure, respectively. Table 6 shows the predicted levels of optimum puffing conditions for sensory properties of explosively puffed ginseng by ridge analysis. The highest scores of overall palatability were obtained at $17.91 \%$ moisture content and 214.30
$\mathrm{kPa}$ puffing pressure.

\section{Optimization of puffing conditions}

Based on the results (Figs. 1 and 2), the trends in extract yield, crude saponin, acidic polysaccharide, and total phenolic content of explosively puffed ginseng as a function of moisture content and puffing pressure were similar, whereas in the case of sensory properties, the trend was different from the functional components of ginseng. Thus, to optimize puffing conditions, contour maps for optimization of the functional components of ginseng and overall palatability of explosively puffed ginseng as a function of moisture content and puffing pressure were superim- 


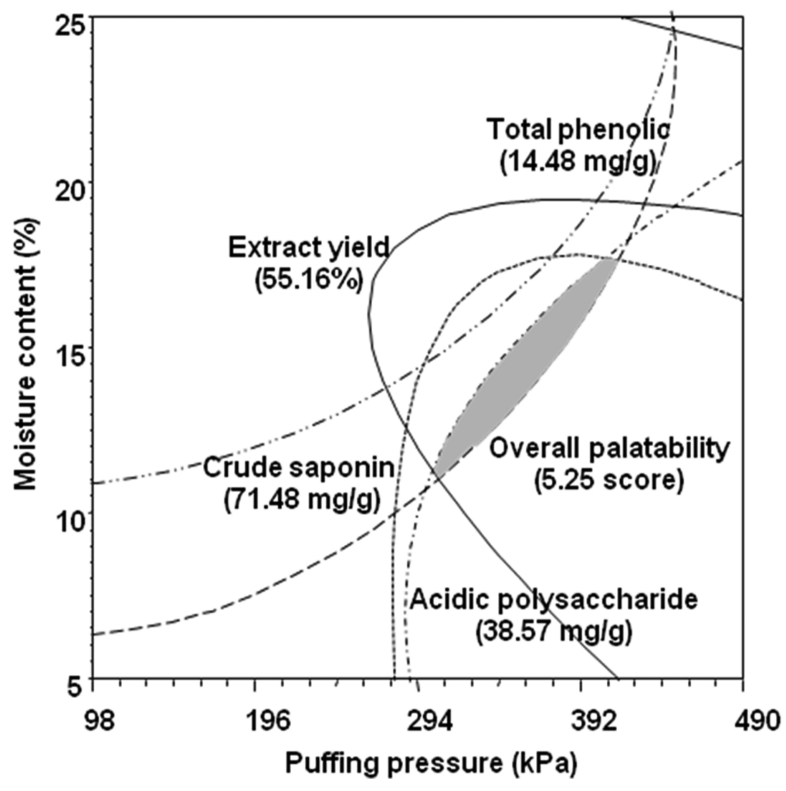

Fig. 3. Superimposed contour map for overall optimization of extract yield, crude saponin, acidic polysaccharide, total phenolic, and overall palatability of explosively puffed ginseng as a function of moisture content and puffing pressure.

posed (Fig. 3). This indicated that extract yield, crude saponin, acidic polysaccharide, total phenolic content, and overall palatability of explosively puffed ginseng could be maximized when puffing was conducted at 10-17\% moisture content and 294-392 $\mathrm{kPa}$ puffing pressure.

In conclusion, the contour maps generated by RSM were successfully applied in puffing process for monitoring and interpreting the combined effects of its operating parameters, such as moisture content and puffing pressure. The puffing conditions were optimized for functional components and sensory properties of explosively puffed ginseng. Based upon these results, the optimized puffing process could be a preferred method for producing functional ginseng products with enhanced sensory properties and reduced processing time.

\section{ACKNOWLEDGEMENT}

The authors would like to express sincere gratitude to the Poongki Specialty Farmer's Association for providing the ginseng samples.

\section{REFERENCES}

1. Jeon HK, Kim SC, Jung NP. Effects of ginseng saponin frac- tion and cyclophosphamide on the tumoricidal activity of mouse macrophage and the antitumor effect. J Ginseng Sci. 105: 15-99 (1991)

2. Korea Ginseng \& Tobacco Research Institute. Korean Ginseng: Chapter 5. Process of ginseng. Korea Ginseng \& Tobacco Research Institute. p 43-62 (1994)

3. Park JD. Recent studies on the chemical constituents of Korean ginseng (Panax ginseng C.A. Meyer). J Ginseng Sci. 20: 389-396 (1996)

4. Payne FA, Taraba JL, Saputa DA. Review of puffing processes for expansion of biological products. J Food Eng. 10: 183-197 (1989)

5. Ryu GH. Extrusion process with gas injection (in Korean). Food Sci Ind. 28: 30-38 (1995)

6. Jang EY, Jin TY, Eun JB. Properties of puffed mulberry-rice snack, Ppeongtuigi by pellet with mulberry leaf and brown rice flour. Korean J Food Sci Technol. 38: 756-761 (2006)

7. Kim JY, Sung KW, Bae HW, Yi YH. pH, acidity, color, reducing sugar, total sugar, alcohol and organoleptic characteristics of puffed rice powder added Takju during fermentation. Korean J Food Sci Technol. 39: 266-271 (2007)

8. Shim GS, Rhee SK. Effects of puffing treatments on the sensory qualities improving of ginseng extract. J. Korean Prof Eng Assoc. 33: 106-115 (2000)

9. Han CK, Hong HD, Kim YC, Kim SS, Sim GS. Effect of puffing on quality characteristics of red ginseng tail root. $\mathrm{J}$ Ginseng Res. 31: 147-153 (2007)

10. Hoseney RC. Principles of cereal science and technology. American Association of Cereal Chemists, Inc., St. Paul (1986)

11. Harper JM. Food extruders and their application. In extrusion cooking. Mercier C. Linko P, Harper JM, eds. AACC, St. Paul, MN. p 1-8 (1989)

12. Ryu GH, Remon JP. Extraction yield of extruded ginseng and granulation of its extracts by cold extrusion-spheronization. J Korean Soc Food Sci Nutr. 35: 899-904 (1994)

13. Ryu GH, Lee JW. Development of extrusion process on red ginseng from raw ginseng and its products. Final Report of Venture Research. Ministry of Health and Welfare, Seoul (2003)

14. Kim ST, Youn KS, Kwon JH, Moon KD. Absorption characteristics of puffed red ginseng lateral root, red ginseng main root and white ginseng lateral root powder. Korean $\mathrm{J}$ Food Preserv. 15: 30-36 (2008)

15. Myers RH, Montgomery DC. Response surface methodology: Process and product optimization using designed experiments (2nd ed.). Wiley, New York (2002)

16. Lee GD, Lee JE, Kwon JH. Application of response surface methodology for food industry. Food Sci Ind. 33: 33-45 (2000)

17. Namba T, Yoshizaki M, Tomimori T, Kobashi K, Matsui K, 
and Hase J. Fundamental studies on the evaluation of the crude drugs. I. Chemical and biochemical evaluation of ginseng and related crude drugs. Yakugaku Zasshi 94: 252-258 (1974)

18. Ando T, Tanaka O, Shibata S. Chemical studies on the oriental plant drugs.(XXY) Comparative studies on the saponins and sapogenins of ginseng and related crude drugs. Yakugaku Zasshi 25: 28-32 (1971)

19. Do JH, Lee HO, Lee SK, Jang JK, Lee SD, Sung HS. Colorimeteric determination of acidic polysaccharide from Panax ginseng, its extraction condition and stability. J Ginseng Sci. 17: 139-144 (1993)

20. American MA, Ough CS. Methods for analysis of musts and wine. Wiley \& Sons, New York, p 176-180 (1958)

21. Meilgaard M, Civile GV, Carr BT. Sensory evaluation techniques. 2nd ed. CRC press, Boston, USA. p 53-54 (1991)

22. Kitagawa, I. Chemical investigation of naturally occurring drug materials. Elucidation of scientific basis for traditional medicines and exploitation of new naturally occurring drugs. Yakugaku Zasshi 112: 1-41 (1992)

23. Shoji, J. Studies on the constituents of ginseng. Natural medicines 53: 55-59 (1999)

24. Ha DC, Ryu GH. Chemical compositions of red, white and extruded root ginseng. J Korea Soc Food Sci Nutr. 34: 247254 (2005)

25. Park MH, Park CK, Lee KS, Kim KC. Changes in the physicochemical properties of ginseng by roasting. Korean J Ginseng Sci. 20: 184-187 (1993)

26. Lee SD, Lee KS, Okuda H, Hwang WI. Inhibitory effect of crude acidic polysaccharide of Korean ginseng on lipolytic action of toxohormone-L from cancerous ascites fluid.
Korea J Ginseng Sci. 14: 10-13 (1990)

27. Okuda, H. Biological activities of non-saponin compounds isolated from Korean red ginseng. Proc. Int'l Ginseng Symp. on Korean Ginseng. The Society for Korean Ginseng. Seoul, Korea, p 15-19 (1990)

28. Nam KY, Ko SR, Choi KJ. Relationship of saponin and nonsaponin for the quality of ginseng. J Ginseng Res. 22: 274283 (1998)

29. Kim YC, Hong HD, Rho J, Cho CW, Rhee YK, Yim JH. Changes of phenolic acid contents and radical scavenging activities of ginseng according to steaming times. J Ginseng Res. 31: 230-236 (2007)

30. Yang SJ, Woo KS, Yoo JS, Kang TS, Noh YH, Lee JS, Jeong HS. Change of Korean ginseng components with high temperature and pressure treatment. Korean J Food Sci Technol. 38: 521-525 (2006)

31. Dewanto V, Wu X, Adom KK, Liu RH. Thermal processing enhances the nutritional value of tomatoes by increasing total antioxidant activity. J Agric Food Chem. 50: 3010-3014 (2002)

32. Choi Y, Lee SM, Chun J, Lee HB, Lee J. Influence of heat treatment on the antioxidant activities and polyphenolic compounds of Shiitake (Lentinus edodes) mushroom. Food Chem. 99:381-387 (2006)

33. Dewanto V, Xianzhong W, Liu RH. Processed sweet corn has higher antioxidant activity. J Agric Food Chem. 50: 49594964 (2002)

34. Turkmen N, Sari F, Velioglu YS. The effect of cooking methods total phenolics and antioxidant activity of selected green vegetables. Food Chem. 93:713-718 (2005) 